KS. JACEK URBAN

\title{
RELACJA KARD. JANA PUZYNY O KONKLAWE 1903 R. I O JEGO SLYNNYM WETO
}

W pierwszych dniach sierpnia 2003 r. minie setna rocznica wyboru kard. Giuseppe Sarto na stolicę Piotrowa, jako Piusa X. Konklawe, które doprowadziło do jego wyboru należy do historii. W czasie jego trwania po raz ostatni w dziejach papiestwa zastosowano weto. W imieniu cesarza Austro-Wegier Franciszka Józefa I zgłosił je biskup krakowski kardynał Jan Puzyna. Cesarz poshużył się ekskluzywa, by nie dopuścić do wyboru kardynała Mariano Rampolli. Tematyka weto została już podjęta i opracowana przez Zdzisława Obertyńskiego ${ }^{1}$. W artykule $\mathrm{Z}$. Obertyńskiego znajduje się notatka, że z punktu widzenia biskupa krakowskiego, jedynym udokumentowaniem bezpośrednim zagadnienia jest właściwie monografia o kardynale Puzynie, pióra ks. Edwarda Komara"2. Autor powtarza zdanie, że kard. Puzyna, poza tym co przekazał Komarowi w formie relacji ustnej, a co Komar zapisał we wspomnieniach o Kardynale, nie pozostawił żadnych materiałów, co więcej wszystkie, które miały związek ze sprawą weta polecił spalić. Dziś to stwierdzenie można już uściślić. Chodzi o źródło nieznane Z. Obertyńskiemu. Jest nim relacja tego, który weto osobiście przedstawił w imieniu cesarza Franciszka Józefa I, biskupa krakowskiego kard. Jana Puzyny. W Archiwum Kapitulnym na Wawelu znajduje się niewielki tekst zapisany ręką kard. Jana Puzyny i przez niego osobiście podpisany. Są to dwie złożone karty papieru. Składkę rozpoczyna odcisk pieczęci wydrukowanej w kolorze czerwonym: Curia Principis Episcopi Cracoviensis. Następnie monogram składający się z pierwszych liter zawołania Jezus-Maryja-Józef (JMJ). Poniżej zamiast tytułu Kard. Puzyna rozpoczął swe świadectwo od słów: „Ku wiecznej pamięci - dla wyświecenia prawdy". Tekst nie jest datowany. Powstał zapewne po serii ataków skierowanych w osobę kard. Puzyny. Zapisany został w formie diariusza, w stylu kard. Puzyny. Zdania są krótkie, rzeczowe. Tekst nie jest przełomem w dotychczasowej wiedzy na ten temat. Relacja kard. Puzyny nie wnosi wiele nowego w stosunku do tego co zanotował Komar we wspomnieniach. Nadal pozostaje otwarte pytanie o postawę kard. J. Puzyny. Czy ce-

${ }^{1}$ Z. O b e r t y ń s k i, Weto kardynała Puzyny, „Collectanea Theologica” A. XXIX, fasc. I-IV, 1958, s. 10-48.

${ }^{2}$ E. K o m a r, Kardynat Puzyna (moje wspomnienia), Krakbw 1912; O be r ty ń s k i, Weto..., s. 16. 
sarz Franciszek Józef I posłużył się ekskluzywą pod wpływem nalegań kardynała Puzyny, który uważał wybór Rampolli za szkodliwy dla Kościoła, czy też kard. Puzyna był tylko portitorem cesarskiego weto ${ }^{3}$. Kard. Puzyna w swej relacji zajmuje stanowisko czysto kościelne, dystansując się od polityki. Swojej relacji nie rozpoczął od audiencji w pałacu cesarskim w Wiedniu, ale od Veni Creator rozpoczynającym konklawe. O politykę zaledwie potrąca pisząc, że papież winien być człowiekiem ,wielkiego serca dla wszystkich narodów"4. Mimo tego relacja kard. Puzyny warta jest publikacji, bo jest nieznaną dotąd historykom Kościoła relacją tego, który w imieniu cesarskim przedstawił weto. Jest ważna, bo w pewnym stopniu uwiarygodnia tekst Komara. Dotąd historycy Kościoła z dużą ostrożnością korzystali z jego wspomnień o kardynale Puzynie. Porównując publikowany tu tekst kard. Puzyny i tekst relacji kard. Puzyny, którą zapisał Komar, wypada za Z. Obertyńskim powtórzyć o Komarze, iż „, spisał tylko to czego był osobiście świadkiem, lub co usłyszał wprost od kardynała (...) przeto jego książka zasługuje na wiarę tam, gdzie przytacza wydarzenia lub wypowiedzi Puzyny"s. Może więc warto zaglądać do wspomnień Komara, skoro konfrontacja z odkrytym tekstem Puzyny, co prawda tylko w tej jednej sprawie, wypada na korzyść późniejszego biskupa administratora diecezji tarnowskiej ${ }^{6}$.

W zamieszczonej poniżej edycji uwspółcześniono pisownię: syxtyńska sykstyńska, No. - nr, missye - misje, St. - św., dyecezalny - diecezjalny itp.

\section{Edycja źródła}

Oryg.: Archiwum Krakowskiej Kapituły Katedralnej na Wawelu, b. sygn.

Ku wiecznej pamięci - dla wyświecenia prawdy.

Konklawe rozpoczęliśmy dnia 31 lipca 1903 w piątek o godzinie 5-tej od Veni Creator w Kaplicy Paulińskiej, skąd udaliśmy się parami do Kaplicy Sykstyńskiej, gdzie przemawiał kard. Oreglia. Przysięga - adoracja Najś[więtszego] S[akramentu], wieczerza wspólna, pod nr 34, widok na plac św. Piotra.

1 sierpnia. Medytacja w kapl[icy] Paulińskiej o 7-mej wspólna Komunia św. w kaplicy Sykst[yńskiej]. Mszę św. miał kard. Ser[a]f[ino] Vanutelli ${ }^{7}$, o 91/2 posiedzenie - modlitwa, wylosowanie skrutatorów, infirmorów, głosowanie, rodzaj przysięgi, złożenie kartek, z głosem do kielicha. Kard. Rampolla 27, Gotti

${ }^{3}$ Z. Obertyński, Kardinal Puzyna und sein Veto, [w:] Festschrift Franz Loidl, Wien 1971, III, s. 183-184; J. K r a c i k, Puzyna Jan, PSB, t. 29, s. 490.

${ }^{4}$ Dla Puzyny Rampolla nadmiernie zwiqzany był z Rosją i Francja. - Por. Komar, Kardynał..., s. 89: ,potrzeba dziś papieża-biskupa, a nie polityka, papieża nie tylko dla dwóch narodowości (Francya i Rosya)".

${ }^{5}$ Z. O berty ń ski, Weto..., s. 16.

${ }^{6}$ A. N o w a k, Stownik biograficzny kapłanów diecezji tarnowskiej 1785-1985, t. 1, Biskupi i kanonicy, Tarnów 1999, s. 33 i ns.

${ }^{7}$ Kard. Serafin Vanutelli, bp de Porto, wicedziekan Kolegium Kardynalskiego, ur. w $1834 \mathrm{r}$. 
17, Sarto $7^{8}$. Kard. Oreglia zapowiedział, że akcesu nie będzie. Zebranie 7 Kardynałów u mnie. Adoracja Najśw[iętszego] Sakr[amentu] w kaplicy Paul[ińskiej], brewiarz. O 41/2 wspólne posiedzenie: R[ampolla] 29, G[otti] 16, S[arto] 10. Byłem u kard. Oreglii ${ }^{9}$ zwracałem [uwage] na niewłaściwą kandydaturę $\mathbf{R}$ [ampolli]. Kard. Ort[eglia] jest za G[ottim]. U mnie narada, mam w niedzielę rano być u kard. Oreg[lii] i oddać protest-ekskluzywę rządu przeciw wyborowi $\mathrm{R}$ [ampolli].

2 sierpnia, niedziela. Miałem Mszę św. o 61/4 w kapli[cy] Paul[ińskiej] przed ołtarzem Najświętszej Maryi Panny. Byłem u kard. Oreg[lii], który odmówił przyjęcia pisma protestującego (veto) przeciw wyborowi R[ampolli], później odwiedziłem kard. Ramp[ollę], któremu powiedziałem, że wniosę protest przeciw jego wyborowi. Byłem u abp Mer[r]y de la Vall. ${ }^{10}$ Msza św. w kaplicy Sykst[yńskiej]. Posiedzenie: R[ampolla] 29, G[otti] 9, S[arto] 21. Po ogłoszeniu wyniku głosowania odczytałem deklaracje z protestem (veto) przeciw wyborowi kard. Ramp[olli]. Wielu kardynałom poddawałem myśl, że przyszły Papież winien być pobożny, wielkiego serca dla wszystkich narodów, rozumiejący pracę biskupa diecezjalnego: małe, wielkie seminaria, misje, wizyta pasterska. Polityka środek - nigdy cel rządów. Posiedzenie o 5-tej godzinie. Kardynał Perraud $^{11}$ wystapif $\mathrm{z}$ mowa przeciw wniesionej ekskluzywie. R[ampolla] 30, S[arto] 24, G[otti] 6, Oreg[lia] $2^{12}$. Poznałem kard. Sarto.

3 sierpnia, poniedziałek. Msza św. o 6-tej w kapl[icy] Pauli[ńskiej]. Posiedzenie o $9 \frac{1}{2}$ - przemówienie $R$ [ampolli] przeciw mej deklaracji. Nic nie wspomniał $\mathrm{w}$ przemówieniu, że poprzednio byłem u niego - mały czlowiek. Agitacja za kard. R[ampolla] (Vives, Mathieu, Steinhuber) ${ }^{13}$. S[arto] 27, $\mathrm{R}$ [ampolla] 24. Kardynał Sarto w ładnym, ciepłym przemówieniu dziękuje za oddane mu głosy, wyboru nie przyjmuje. Poszedłem z kard. Sarto do Kapl[icy] Paul[ińskiej]. Posiedzenie o 5-tej. S[arto] 35, R[ampolla] 16, G[otti] 7. Kard. Satolli ${ }^{14}$ oznajmił, że kard. S[arto] wybór przyjmie. Byłem u kard. Koppa i Fischera $^{15}$.

4 Sierpnia, [wspomnienie] św. Dominika. Msza św. w Kapl[icy] Paul[ińskiej]. O 9 1 1/2 w kapl[icy] Sykst[yńskiej]; posiedzenie. S[arto] 50, R[ampolla] 10,

${ }^{8}$ Kard. Marian Rampolla del Tindaro, sekretarz stanu Leona XIII, kard. Hieronim Maria Gotti prefekt Kongregacji Biskupów i Zakonów, kard. Józef Sarto patriarcha wenecki. Wg F. Seppelt, K. Loeffler, Dzieje papieży, Poznań 1936, s. 606 podczas I głosowania kard. Sarto otrzymal 5 głosów.

${ }^{9}$ Kard. Ludwik Oreglia di San Stefano, biskup Ostii i Velletri, dziekan Kolegium Kardynalskiego, ur. $1828 \mathrm{r}$.

${ }^{10}$ Abp Rafał Merry del Val był sekretarzem konklawe. W edycji pozostawiono pisownię Autora: de la Vall, zamiast del Val.

${ }^{11}$ Kard. Adolf Perraud, bp Autun.

${ }^{12}$ Wg F. S e p pelt, K. L o effler, Dzieje papieży, s. 606 w IV głosowaniu Gotti otrzymał 3 głosy.

${ }^{13}$ Kard. Andrzej Steinhuber, prefekt Kongregacji Indeksu, kard. Józef Vives y Tuto, generał kapucynów i kard. Franciszek Mathieu.

${ }^{14}$ Kard. Franciszek Satolli, bp Frascati, prefekt Kongregacji Studiów.

${ }^{15}$ Kard. Jerzy Kopp, bp Wrocławia, kard. Antoni Fischer, abp Kolonii. 
G[otti] 2. Kardynał Sarto poszedł się ubrać w białą sutannę. Oznajmił, że obiera imię Piusa X. Zaraz w kapl[icy] Syxt[yńskiej] złożyliśmy hotd Piusowi X, który poprzedzony przez kardynałów dał z logii bazyliki benedykcję do wnętrza bazyliki św. Piotra zebranym wiernym ${ }^{16}$. Głos ładny, silny. Poczem poszedł Pius $\mathrm{X}$ do chorego kard[ynała] hiszpań[skiego]. O 5-ej godzinie w kapie jedwabnej, fioletowej składaliśmy hołd po raz drugi w kaplicy Sykstyńskiej Piusowi X (w kapie czerwonej i mitrze). Ściskał i błogosławił. Na sesjach w czasie konklawe kardynałowie byli ubrani we fioletową sutannę, mucet.

4 sierpnia o godzinie $6 \frac{1}{2}$ wyjechaliśmy z Watykanu.

(+J. Kard. Puzyna)

${ }^{16}$ Dlaczego Pius X nie udzielił błogosławieństwa urbi et orbi z zewnętrznej logii bazyliki św. Piotra zob. Z. Z i l lińs ki, Papiestwo i Papieże dwóch ostatnich wieków, Warszawa 1999 , s. 257. 